\title{
PENGARUH VARIETAS, PEROMPESAN DAUN, DAN PENYEMPROTAN FUNGISIDA TERHADAP INTENSITAS PENYAKIT KARAT (Puccinia horiana P. Henn.) PADA TANAMAN KRISAN (Dendranthema grandiflora Tzvelev)
}

\author{
THE EFFECT OF VARIETIES, DEFOLIATION, AND APPLICATION OF \\ FUNGICIDE AGAINST RUST (Puccinia horiana P. Henn.) INTENCITY ON \\ CHRYSANTHEMUM (Dendranthema grandiflora Tzvelev)
}

\author{
E. Silvia Yusuf ${ }^{1}$ dan Suhardi $^{1}$
}

Diterima 7 Januari 2013, disetujui 28 Juni 2013

\begin{abstract}
Puccinia horiana P. Henn. is the pathogen which caused of white rust on chrysanthemum. It is the most serious disease on chrysanthemum. Study on the effect of varieties, defoliation, and fungicide application against rust diseases (Puccinia horiana) was carried out under plastic house of Institute of Ornamental Crop Research at Segunung (alt. $1100 \mathrm{~m}$ asl) from July - November 2008, using Split-split plot design in three (3) replications. The main plot was chrysanthemum cultivar (cv. ILK.6B1, cv. Giant and cv. Cat eye); sub-plot was defoliation and sub-sub plot was application of fungicide. The results indicated that a) cv. Cat Eye, cv. ILK.6B1(aster/Reagent) and cv. Giant were resistant, moderately resistant, and susceptible against rust caused by Puccinia horiana respectively; b) defoliation was able to reduce disease intensity of rust as much as 44 percent at the beginning, but only 3-21 percent on the further observations; c) fungicide application was able to reduce disease intensity as much as 20-49 percent; $d$ ) defoliation and fungicide application did not significantly influence the number of flowers, plant height and flower diameter.
\end{abstract}

Keywords: Dendranthema grandiflora, Puccinia horiana, resistant variety, defoliation, fungicide application.

\section{PENDAHULUAN}

Krisan (Dendranthema grandiflora Tzvelev) merupakan salah satu bunga potong yang digemari oleh masyarakat. Permintaan bunga krisan di pasar bunga Rawabelong, Jawa Barat pada tahun 2001 menduduki peringkat pertama di antara permintaan bunga lainnya dengan jumlah kuntum mencapai 5.574.670 (Nurmalinda et al 2004). Pada tahun 2007, Jawa Barat menjadi provinsi yang memberikan kontribusi terbesar $(70 \%)$ terhadap produksi nasional krisan dengan produksi 47.090.861 tangkai (Direktorat Jenderal Hortikultura 2008). Tanaman krisan juga

\footnotetext{
${ }^{1}$ Balai Penelitian Tanaman Hias email:silviayusuf@yahoo.co.id Jl. Raya Ciherang, Pacet, Cianjur P.O. BOX 8 SDL 43253
}

dibudidayakan di Jawa Tengah, Jawa Timur, Yogyakarta, Sumatera Utara, Sumatera Barat, Sumatera Selatan, Lampung, dan Sulawesi Utara.-

Kualitas bunga krisan dan bunga potong lainnya merupakan faktor utama yang menentukan preferensi konsumen, walaupun terdapat faktor lainnya seperti perbedaan selera dan trend. Salah satu kendala yang menentukan kualitas bunga potong ialah kerusakan daun dan/atau bunga baik karena fisik maupun biotik. Menurut Kristina et al. (1994) adanya serangan karat, thrips atau bercak di daun/bunga krisan menurunkan kesegarannya, sehingga vase-lifenya hanya 5 hari, padahal untuk bunga yang sehat tanpa cacat vase-lifenya dapat mencapai 12 hari. 
Penyakit karat (white rust) yang disebabkan oleh Puccinia horiana P. Henn merupakan penyakit yang paling penting, sebab kehadirannya mengakibatkan kerusakan di daun secara nyata dan menurunkan kualitas bunga. Gejala kerusakan berupa pustul-pustul berwarna putih kotor di sisi daun sebelah bawah dengan ukuran yang bervariasi. Pustul yang menyatu dapat menimbulkan bercak nekrotik dan kematian daun. Serangan pada daun-daun yang terdapat di sekitar bunga menurunkan nilai estetika dan nilai komersial bunga. Kehilangan hasil akibat serangan penyakit itu mencapai 30 persen hingga 100 persen (Suhardi 2009 dan Ellis 2007).

Di antara varietas krisan yang ditanam

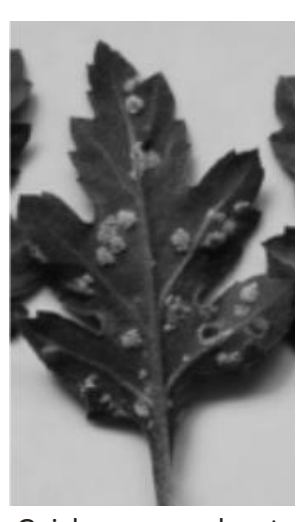

Gejala serangan karat pada krisan menanggulangi penyakit tersebut ialah propineb dan mankozeb yang menempati 13-32 persen dari biaya produksi total (Suhardi 2009). Selain fungisida tersebut, di PT Alinda dan Ciputri juga digunakan fungisida heksakonazol (Anvil ${ }^{\mathrm{R}} 250$ SC) dan benomil (Belate ${ }^{R} 50 \mathrm{WP}$ ) dengan jumlah yang lebih sedikit. Fungisida berbahan aktif $\mathrm{Cu}$ tidak dapat menekan perkembangan penyakit karat, sementara Ni cenderung meningkatkannya (Djatnika et al. 1994). Tujuan dari penelitian ini ialah untuk mendapatkan teknologi pengendalian penyakit karat (P. horiana) pada tanaman krisan.

\section{BAHAN DAN METODE}

Penelitian ini dilakukan di rumah plastik Balai Penelitian Tanaman Hias Segunung $(1100 \mathrm{mdpl}$ ) dari bulan Juli - November 2008. Petak-petak percobaan disusun berdasarkan rancangan Split-split Plot dengan 3 (tiga) ulangan. Petak utama adalah 3 varietas krisan, anak petak adalah perlakuan perompesan (dirompes dan tidak) dan anak-anak petak berupa peyemprotan fungisida (disemprot dan tidak). Dengan demikian terdapat 12 perlakuan dan seluruh petak percobaan berjumlah 36 petak. Setiap petak percobaan terdiri atas 100 tanaman dengan jarak tanam $12,5 \mathrm{~cm} \times 12,5 \mathrm{~cm}$. Jarak antar petak utama $75 \mathrm{~cm}$, jarak antar anak petak dan anak-anak petak $50 \mathrm{~cm}$ (Lampiran 1). Karena keterbatasan material tanam (stek), waktu tanam tiap blok percobaan (ulangan) berbeda dengan selisih waktu satu minggu.

Petak utama (Varietas): Varietas krisan terdiri atas cv. ILK.6B1 (Aster atau Reagent warna Ungu), cv. Giant (warna putih), dan cv. Cat Eye (warna kuning). Ketiga varietas merupakan krisan jenis spray yang banyak dibudidayakan oleh petani di daerah Cipanas, Cianjur. Bibit krisan berasal dari petani (PT Ingu Laut) berupa stek pucuk berumur 12 hari, berasal dari tanaman induk yang dipelihara pada hari panjang.

Anak petak (Perompesan daun): Perlakuan terdiri atas tanaman dirompes dan tidak dirompes. Kegiatan ini berupa pembuangan daun/tunas 
bagian bawah dengan tujuan untuk mengurangi kelembaban. Perompesan dilakukan sekali pada saat keluar primordia bunga, yaitu daun-daun dan tunas-tunas aksiler sampai setinggi $25 \mathrm{~cm}$ dari permukaan tanah dipetik dan dimusnahkan.

Anak-anak petak (Penyemprotan fungisida): Perlakuan terdiri atas tanaman yang tidak disemprot fungisida dan yang disemprot fungisida bila intensitas serangan mencapai 10 persen. Fungisida yang digunakan ialah: heksakonazol $\left(\right.$ Anvil $\left.^{\mathrm{R}} 250 \mathrm{SC}\right)$, propineb (Antracol $\left.{ }^{\mathrm{R}} 70 \mathrm{WP}\right)$, dan benomil (Benlate ${ }^{\mathrm{R}} 50 \mathrm{WP}$ ) yang diaplikasikan secara bergantian. Pada saat aplikasi fungisida dilakukan, setiap sisi petak diberi penghalang plastik agar perlakuan tidak mengenai plot perlakuan lainnya.

\section{Kultur teknis}

Pupuk kandang (kotoran kuda) halus yang telah dikomposkan dengan formula EM4 selama 15 hari dengan dosis $5 \mathrm{~kg} /$ petak (setara dengan 32 ton/ ha) diberikan sebelum tanam. Setelah pemberian pupuk kandang lahan didisinfektasi dengan dazomet (Basamid) dengan dosis 4,6 g/petak (setara dengan $30 \mathrm{~kg} / \mathrm{ha}$ ) selama 15 hari.

Penyinaran tambahan dilakukan selama 35 hari dengan menggunakan lampu pijar 75 watt, jarak antar lampu 2,0 $\mathrm{m}$ dan ketinggian 1,75 $\mathrm{m}$ dari permukaan tanah. Penyinaran diberikan tiap malam antara jam 22.00-02.00.

Pupuk NPK (15:15:15) dengan dosis 0,09 kg/petak (setara dengan $600 \mathrm{~kg} / \mathrm{ha}$ ) diberikan $3 \mathrm{kali}$, yaitu pada umur 3, 6, dan 9 minggu setelah tanam (Sutater 1992). Pengendalian hama dilakukan dengan menyemprotkan abamektin $\left(\right.$ Agrimec $^{\mathrm{R}} 18$ EC, $0,2 \mathrm{ml} / \mathrm{l}$ ) sesuai keperluan, terutama untuk pengendalian kutu daun, pengorok daun dan thrips.

Pengamatan terhadap intensitas karat daun dilakukan pada 12 tanaman sampel yang ditentukan secara sistematis dengan metode skoring kerusakan (indeks penyakit) $0 \mathrm{~s} / \mathrm{d} 5$ yaitu $0=$ tidak ada serangan; $1=1-10$ persen kerusakan daun; $2=11-20$ persen kerusakan daun; $3=20-40$ persen kerusakan daun; $4=41-80$ persen kerusakan daun; $5=>80$ persen kerusakan daun.

Intensitas serangan rata-rata per petak dihitung dengan formula sebagai berikut:

$\mathrm{I}=100 \Sigma(\mathrm{vxn}) /(\mathrm{Z} \times \mathrm{N})$ persen dimana $\mathrm{I}=$ intensitas penyakit $(\%) ; \mathrm{v}=$ nilai skore tiap kategori serangan; $\mathrm{n}=$ jumlah tanaman tiap kategori serangan; $Z=$ nilai skore dari kategori tertinggi; $\mathrm{N}=$ jumlah tanaman yang diamati. Selain intensitas serangan diamati juga tinggi tanaman, jumlah bunga mekar saat panen, jumlah bunga masih kuncup, dan rata-rata diameter bunga mekar.

Data pengamatan dianalisis menggunakan analisis sidik ragam (ANOVA) dan diuji lanjut dengan menggunakan uji jarak berganda Duncan (DMRT) 5 persen.

\section{HASIL DAN PEMBAHASAN}

Dari analisis sidik ragam menunjukkan bahwa tidak terdapat pengaruh interaksi petak utama (varietas) dengan anak petak (perompesan daun) dan anak-anak petak (penyemprotan fungisida) terhadap semua peubah yang diamati. Demikian juga tidak ada pengaruh interaksi antara anak petak dengan anak-anak petak. Pengaruh yang sangat nyata terhadap intensitas penyakit karat ialah ulangan (blok) dan varietas krisan, sedangkan perompesan serta perlakuan fungisida pengaruhnya tidak nyata pada semua pengamatan.

Varietas tahan sebagai salah satu komponen dalam pengendalian penyakit mempunyai pengaruh sangat nyata terhadap perkembangan penyakit karat yang disebabkan oleh $P$. horiana. Pada cv. Cat Eye dengan bunga berwarna kuning intensitas penyakit karat sangat rendah dan berbeda nyata dibanding cv. ILK.6B1 dan cv.Giant, sedangkan intensitas penyakit karat pada $\mathrm{cv}$. ILK.6B1 lebih rendah dibanding cv. Giant. Tingkat resistensi cv. ILK.6B1 (aster atau Reagent) dengan bunga berwarna ungu kemerah-merahan adalah moderat. Dengan kriteria resistensi yang digunakan oleh Djatnika et al. (1994) maka cv. Cat Eye termasuk varietas yang tahan, cv. ILK.6B1 moderat tahan, dan cv. Giant rentan 
terhadap penyakit karat. Perbedaan resistensi pada setiap kultivar terhadap patogen disebabkan beberapa hal diantaranya ialah struktur pertahanan jaringan tanaman yang meliputi ukuran, letak dan bentuk stomata (Hanudin et al 2004).
Penyemprotan fungisida berdasarkan ambang kendali 10 persen tingkat kerusakan berpengaruh nyata terhadap intensitas serangan karat pada pengamatan 28 dan 56 hst serta saat panen, sedangkan pada pengamatan 14 dan 42 hst tidak berpengaruh nyata. Namun aplikasi fungisida

Tabel 1. Rata-rata intensitas serangan karat dalam petak utama, anak petak, dan anak-anak petak [Average of rust disease intensity in main plot, sub plot, and sub-sub plot]

\begin{tabular}{|c|c|c|c|c|c|}
\hline \multirow[t]{2}{*}{ Perlakuan (Treatment) } & \multicolumn{5}{|c|}{$\begin{array}{c}\text { Intensitas serangan penyakit .......hari setelah tanam (Rust disease intensity ... } \\
\text { days after planting), (\%) }\end{array}$} \\
\hline & 14 & 28 & 42 & 56 & Saat panen \\
\hline \multicolumn{6}{|l|}{ Varietas (Varieties) } \\
\hline cv. ILK.6B1 & $10,22 \mathrm{~b}$ & $6,94 \mathrm{~b}$ & $17,13 \mathrm{~b}$ & $20,92 \mathrm{~b}$ & $13,90 \mathrm{~b}$ \\
\hline cv. Giant & $25,71 \mathrm{a}$ & $32,94 \mathrm{a}$ & $36,25 \mathrm{a}$ & 39,36 a & $21,80, a$ \\
\hline cv.Cat eye & $3,00 \mathrm{~b}$ & $4,96 \mathrm{~b}$ & $7,35 \quad \mathrm{c}$ & $10,23 \mathrm{c}$ & $4,62 \mathrm{c}$ \\
\hline \multicolumn{6}{|l|}{$\begin{array}{l}\text { Perompesan daun } \\
\text { (Defoliation) }\end{array}$} \\
\hline Tidak dirompes & $16,60 \mathrm{a}$ & $15,15 \mathrm{a}$ & $21,65 \mathrm{a}$ & $25,18 \mathrm{a}$ & $15,07 \mathrm{a}$ \\
\hline Dirompes & $9,28 \mathrm{~b}(44)$ & 14,66 a (3) & 18,85 a $(13)$ & 21,83 a (13) & $11,81 b(22)$ \\
\hline \multicolumn{6}{|l|}{$\begin{array}{l}\text { Penyemprotan } \\
\text { Fungisida (Fungicide } \\
\text { spraying) }\end{array}$} \\
\hline Tidak disemprot & $15,49 \mathrm{a}$ & $18,91 \mathrm{a}$ & $22,76 \mathrm{a}$ & $31,18 \mathrm{a}$ & $14,92 \mathrm{a}$ \\
\hline Disemprot & 10,46 a $(32)$ & $10,90 \mathrm{~b}(42)$ & $17,74 \mathrm{a}(22)$ & $15,83 \mathrm{~b}(49)$ & $11,97 b(20)$ \\
\hline
\end{tabular}

Angka rata-rata perlakuan dalam tiap faktor yang diikuti oleh huruf yang sama menunjukkan tidak berbeda nyata menurut uji jarak berganda Duncan 5 persen. Angka dalam kurung adalah nilai penurunan intensitas penyakit karat karena perlakuan, (\%)[Average figure in every factor followed by the same letter indicates no significant different at 5 persen DMRT; figure between bracket is disease reduction because of treatment, \%)

Pengaruh perompesan terhadap intensitas penyakit karat nyata terlihat pada pengamatan 14 hari setelah tanam (hst). Perompesan menurunkan intensitas serangan karat sampai 44 persen. Hal tersebut disebabkan oleh berkurangnya daundaun sakit karena dibuang (dirompes). Pada pengamatan selanjutnya pengaruhnya tidak nyata diduga karena, sebagai penyakit yang air-borne, sumber inokulum berasal dari mana saja termasuk dari tanaman yang tidak dirompes. Walaupun secara statistik tidak nyata namun perompesan mampu menurunkan intensitas serangan karat antara 3-13 persen, sedangkan pada pengamatan saat panen, perompesan tampak berpengaruh nyata karena dibuangnya sebagian daun-daun yang sakit dan menurunkan serangan sebesar 22 persen. dapat menurunkan intensitas penyakit karat, yaitu 20-49 persen. Kesulitan yang dihadapi dalam pengendalian penyakit, dan juga hama, pada tanaman krisan ialah pertanaman yang sangat rapat sehingga pestisida yang disemprotkan tidak dapat mencapai bagian tanaman yang ada di tengah. Menurut Silvia et al (2012) aplikasi fungisida dengan bahan aktif mancozeb dapat menurunkan intensitas serangan karat putih hingga 50 persen.

Pengaruh interaksi petak utama dengan anak petak dan anak-anak petak juga tidak dijumpai pada berbagai peubah yang lain seperti jumlah bunga mekar/kuncup, tinggi tanaman dan diameter bunga. Bunga mekar/kuncup adalah bunga yang dihasilkan oleh 3 (tiga) cabang yang dipelihara 
setelah pincing bunga terminalnya; tinggi tanaman diukur dari permukaan tanah sampai bunga yang paling tinggi; diameter bunga adalah rata-rata dari 5 (lima) bunga mekar penuh.

Tabel 2 menunjukkan pengaruh varietas, perompesan, dan perlakuan fungisida terhadap jumlah bunga mekar/kuncup saat panen, tinggi tanaman serta diameter bunga. Di sini tampak hanya blok dan petak utama (varietas) yang pengaruhnya berbeda nyata terhadap beberapa peubah.

Varietas krisan berpengaruh pada jumlah bunga mekar/kuncup, tinggi tanaman, dan diameter bunga. Jumlah bunga mekar/kuncup cv. Cat Eye (13 bunga) berbeda nyata dibanding cv. Giant (10,6 bunga); sementara tidak terdapat beda yang nyata antara cv. Cat Eye dengan cv. ILK.6B1 baik bunga mekar maupun kuncup. Kristina et al. 1994 menyatakan bahwa di tingkat petani jumlah bunga per tangkai berkisar antara 3-12

Nisbah bunga mekar vs kuncup mencerminkan keserempakan waktu bunga mekar. Semakin besar variasi waktu bunga mekar, makin rendah mutunya karena lebih sulit diatur dalam vas peragaan.

Tinggi tanaman semua varietas memenuhi standar sebagai bunga potong yaitu antara $123 \mathrm{~cm}$ (cv. Cat Eye) sampai $133 \mathrm{~cm}$ (cv, Giant). Menurut Budiarto et al (2007) kualitas fisik ini dalam SNI tergolong dalam kelas mutu A hingga AA. Kristina et al. (1994) melaporkan bahwa produsen besar menghasilkan krisan dengan panjang tangkai 30$50 \mathrm{~cm}$, sedangkan produsen kecil $35-50 \mathrm{~cm}$.

Diameter bunga antar varietas berbeda nyata antara cv. ILK.6B1 dan cv. Giant, masing-masing $18 \mathrm{~mm}$ di satu pihak dibanding cv. Cat eye di pihak lain (12 mm); sedangkan antara cv. ILK.6B1 dan cv. Giant tidak terdapat perbedaan diameter bunga secara nyata. Perlakuan perompesan dan fungisida tampaknya tidak berpengaruh nyata terhadap peubah-peubah jumlah bunga mekar/kuncup, tinggi tanaman (tangkai) serta diameter bunga. Namun perompesan dan penyemprotan fungisida tidak dapat ditinggalkan begitu saja mengingat

Tabel 2. Rata-rata jumlah bunga mekar, kuncup, tinggi tanaman serta diameter bunga (Average of open flower, bud, plant height and flower diameter)

\begin{tabular}{|c|c|c|c|c|}
\hline \multirow[b]{2}{*}{ Perlakuan (Treatment) } & \multicolumn{4}{|c|}{ Peubah yang diamati saat panen } \\
\hline & $\begin{array}{l}\text { Bunga mekar } \\
\qquad(\%)^{1)}\end{array}$ & ${ }_{2)}$ Bunga kuncup & $\begin{array}{c}\text { Tinggi tangkai } \\
\text { 3) } \\
(\mathrm{cm})\end{array}$ & $\begin{array}{c}\text { Diameter } \\
\left.\text { bunga }{ }^{4}\right) \\
(\mathrm{mm})\end{array}$ \\
\hline \multicolumn{5}{|l|}{ Varietas (Varieties) } \\
\hline cv. ILK.6B1 & $11,32 \mathrm{ab}$ & $12,23 \mathrm{a}$ & $125,0 \mathrm{~b}$ & $18,09 \mathrm{a}$ \\
\hline cv.Giant & $10,67 \mathrm{~b}$ & $6,33 \mathrm{~b}$ & $137,7 \mathrm{a}$ & $17,87 \mathrm{a}$ \\
\hline cv.Cat Eye & $13,48 \mathrm{a}$ & $10,62 \mathrm{a}$ & $123,9 \mathrm{~b}$ & $12,45 \mathrm{~b}$ \\
\hline \multicolumn{5}{|c|}{ Perompesan daun (Defoliation) } \\
\hline Tidak dirompes & $11,13 \mathrm{a}$ & $10,26 \mathrm{a}$ & $128,7 \mathrm{a}$ & $15,92 \mathrm{a}$ \\
\hline Dirompes & $11,51 \mathrm{a}$ & $9,20 \mathrm{a}$ & $129,1 \mathrm{a}$ & 16,36 a \\
\hline \multicolumn{5}{|c|}{$\begin{array}{c}\text { Penyemprotan Fungisida (Fungicide } \\
\text { spraying) }\end{array}$} \\
\hline Tidak disemprot & $11,94 \mathrm{a}$ & $9,60 \mathrm{a}$ & $129,5 \mathrm{a}$ & $15,29 \mathrm{a}$ \\
\hline Disemprot & $11,70 \mathrm{a}$ & $9,86 \mathrm{a}$ & $128,3 \mathrm{a}$ & $16,48 \mathrm{a}$ \\
\hline \multicolumn{5}{|c|}{$\begin{array}{l}\text { 1) dan }{ }^{2)} \text { Bunga mekar/kuncup adalah bunga yang dihasilkan oleh } 3 \text { cabang yang dipelihara setelah pincing bunga } \\
\text { terminalnya; }{ }^{3)} \text { tinggi tanaman diukur dari permukaan tanah sampai bunga yang paling tinggi; }{ }^{4)} \text { diameter bunga adalah rata- } \\
\text { rata dari } 5 \text { bunga mekar penuh (Open flowers and buds at three stem remaining after pinching of terminal flower; three } \\
\text { plant height) } \\
\text { Angka rata-rata perlakuan dalam tiap faktor yang diikuti oleh huruf yang sama menunjukkan tidak berbeda nyata menurut } \\
\text { uji jarak berganda Duncan } 5 \text { persen. (\%) [Average figure in every factor followed by the same letter indicates no significant } \\
\text { different at } 5 \text { persen DMRT) }\end{array}$} \\
\hline
\end{tabular}


kedua teknik budidaya tersebut dapat mengurangi intensitas serangan karat dan pada gilirannya meningkatkan mutu bunga.

Tinggi tanaman semua varietas memenuhi standar sebagai bunga potong yaitu antara $123 \mathrm{~cm}$ (cv. Cat Eye) sampai $133 \mathrm{~cm}$ (cv, Giant). Menurut Budiarto et al (2007) kualitas fisik ini dalam SNI tergolong dalam kelas mutu Ahingga AA. Kristina et al. (1994) melaporkan bahwa produsen besar menghasilkan krisan dengan panjang tangkai 30$50 \mathrm{~cm}$, sedangkan produsen kecil $35-50 \mathrm{~cm}$.

Diameter bunga antar varietas berbeda nyata antara cv. ILK.6B1 dan cv. Giant, masing-masing $18 \mathrm{~mm}$ di satu pihak dibanding cv. Cat eye di pihak lain (12 mm); sedangkan antara cv. ILK.6B1 dan cv. Giant tidak terdapat perbedaan diameter bunga secara nyata. Perlakuan perom-pesan dan fungisida tampaknya tidak berpengaruh nyata terhadap peubah-peubah jumlah bunga mekar/kuncup, tinggi tanaman (tangkai) serta diameter bunga. Namun perom-pesan dan penyemprotan fungisida tidak dapat ditinggalkan begitu saja mengingat kedua teknik budidaya tersebut dapat mengurangi intensitas serangan karat dan pada gilirannya meningkatkan mutu bunga.

\section{KESIMPULAN}

1. cv. Cat eye, cv. ILK.6B1(aster atau Reagent) dan cv. Giant masing-masing merupakan varietas krisan yang tahan, moderat tahan, dan rentan terhadap karat yang disebabkan oleh Puccinia horiana P. Henn.

2. Perompesan mampu menurunkan intensitas serangan karat sampai 44 persen pada tahap awal, namun pada tahap selanjutnya 3-21 persen.

3. Penyemprotan fungisida dapat menurunkan intensitas penyakit karat yang cukup berarti yaitu 20-49 persen.

4. Perlakuan perompesan dan fungisida tampaknya tidak berpengaruh nyata terhadap peubahpeubah jumlah bunga mekar/kuncup, tinggi tanaman (tangkai) serta diameter bunga.

\section{DAFTAR PUSTAKA}

Budiarto, K, E.D.S. Nugroho, Y. Sulyo dan M. Soedarjo. 2007. Pertumbuhan dan kualitas bunga krisan potong tipe spray dan standar pada dua konstruksi rumah plastik. J. Hort. Ed. Khusus (2):148-153.

Djatnika, I, Maryam Abn dan Samijan 1994. Pengaruh penyiangan dan aplikasi fungisida $\mathrm{Cu}$ dan Ni terhadap intensitas penyakit karat dan populasi kutu daun. Bul. Pen. Tan. Hias 2(2): 51-59.

Direktorat Jenderal Hortikultura. 2008. Statistik produksi hortikultura tahun 2007. Departemen Pertanian. 231 hal.

Ellis, D. 2007. New Pest Concern in New England; Chrysnthemum White Rust. Integrated Pest Management, Univ. Connecticut. 1 hal.

Hanudin, K. Kardin dan Suhardi. 2004. Evaluasi ketahanan klon-klon krisan terhadap penyakit karat putih. J. Hort. 14(Ed. khusus): 430-441

Kristina, D., D. Herlina, S. Wuryaningsih. 1994. Inventarisasi dan karakterisasi beberapa jenis bunga potong komersial di pasar bunga Cipanas, Lembang, Bandung dan Jakarta. Bul. Pen. Tan. Hias 2(1): 7-19.

Nurmalinda, D. Herlina dan Satsijati. 2004. Studi diagnostik eksploratif perkembangan tanaman hias potensial. J. Hort. 14(Ed. khusus): 442-453.

Ridwan, H., Nurmalinda dan H. Supriadi. 2005. Analisis luas minimum usahatani bunga krisan potong. J. Hort. 15(4):303-311.

Suhardi 2009. Sumber Inokulum, Respons varietas, dan efektivitas fungisida terhadap penyakit karat putih pada tanaman krisan. J. Hort. 19 (2): 207- 213. 
Silvia Yusuf, E., Suhardi dan Saepuloh. tahun? Uji efektivitas isolat-isolat Cladosporium sp. dalam mengendalikan penyakit karat putih (Puccinia horiana) pada tanaman krisan di lapangan. Laporan hasil penelitian. Balai Penelitian Tanaman Hias. Belum dipublikasikan. 20 hal. 